\title{
Cytomixis in Pollen Mother Cells of Polygonum tomentosum Schrank
}

\author{
Soliman A. Haroun \\ Biology Department, Faculty of Education, Tanta University, Kafr El Sheikh, 3312, Egypt
}

Accepted June 21, 1995

Cytomixis refers to the migration of chromatic material from one cell to an adjacent cell through cytoplasmic connections. It was first recorded by Kronicke (1901) in pollen mother cells (PMS) of Crocus sativus, and occurs in several families of flowering plants (Bell 1964, Cheng et al. 1975, Kamara 1960, Narain 1979, Omara 1976, Sirvastav and Rain 1980). Cytomixis is generally reported during microsporogensis in genetically unbalanced plants such as hybrids (de Nettancourt and Grant 1964), mutants (Gottschalk 1970, Datta and Biswas 1984), triploids (Salesses 1970), apomicts (Mantu and Sharma 1983), plants affected by triflurine (Bobak and Harich 1978) and even in some normal diploids (Sapre 1978, Chauhan 1981).

Cytomixis has also been recognised in somatic cells (Bowes 1973, Jacob 1941, Brown 1947, Sarvella 1958, Tarkowska 1960, 1965), at the interface between somatic and meiotic cells (Cooper 1952) and in the epidermal cells of scales and leaves (Tarkowska 1960, 1965).

Very little is known about the occurence, cause or significance of cytomixis. HeslopHarrison (1966) reported that cytomixis normally allows the exchange of cell organelles between cells. However Omara (1976) suggested that this process can represent a real migration of chromatic material between cells during meiosis. Sarvella (1958), Bell (1964) and Sapre and Dayarani (1987) have stated that cytomixis may be a cause of many polyploid and aneuploid forms in many species of plant.

During a programme of cytological studies on Egyptian members of the Polygonaceae, cytomixis was observed only in Polygonum tomentosum. This distinctive plant is considered by Akeroyd (1993) to fall within the widespread species $P$. lapathifolium L. Previous counts have shown it to have $2 \mathrm{n}=22$ (Bolkhovskikh et al. 1969). It is an annual ruderal of wet mud.

\section{Materials and methods}

Preanthesis flower buds were collected from five localities near Rashid City, Behera governate, Egypt between 8 a.m. and 10 a.m. Buds were fixed in a freshly prepared solution of absolute ethanol and glacial acetic acid $(3 / 1, \mathrm{v} / \mathrm{v})$ for $24 \mathrm{hr}$. Buds were later stored in $70 \%$ ethanol at $4{ }^{\circ} \mathrm{C}$. Both fixed and freshly collected anthers were squashed in $2 \%$ acetocarmine using an iron needle. Pollen grains were also stained in acetocarmine to study pollen stainability. Photographs were taken from freshly prepared slides using a Richter photostar research microscope with automatic camera.

\section{Results and discussion}

Many authers suggest that cytomixis is an artifact of fixation (Linnert 1955, Takats 1959, Ahadi and Sharma 1988). However, I found that it occurs at an equal frequency in fixed and freshly stained material.

In $P$. tomentosum, cytomixis is represented by a variety of conditions ranging from empty 
cytoplasmic connections (Figs. 3, 7) to complete cell fusion (Fig. 2), sometimes rows of up to four cells are connected together (Fig. 1). In some cases, cells showed multiple connections, as was also reported by Ahadi and Sharma (1988) and Basavaiah and Murthy (1987). In both meiosis I and meiosis II, cell fusions formed about $17 \%$ of cytomictic events (Table 1). The total proportion of PMC's showing cytomixis was $20 \%$, and this did not differ significantly between populations.

In general, cytomixis was less commonly observed in meiosis II than in meiosis I, as reported by Bahl and Tyagi (1988) and Ahadi and Sharma (1988). Cytomictic connections observed during metaphase and prophase of meiosis I, II (Figs. 3, 7) typically contained univalents and disoriented chromosomes (Fig. 3).

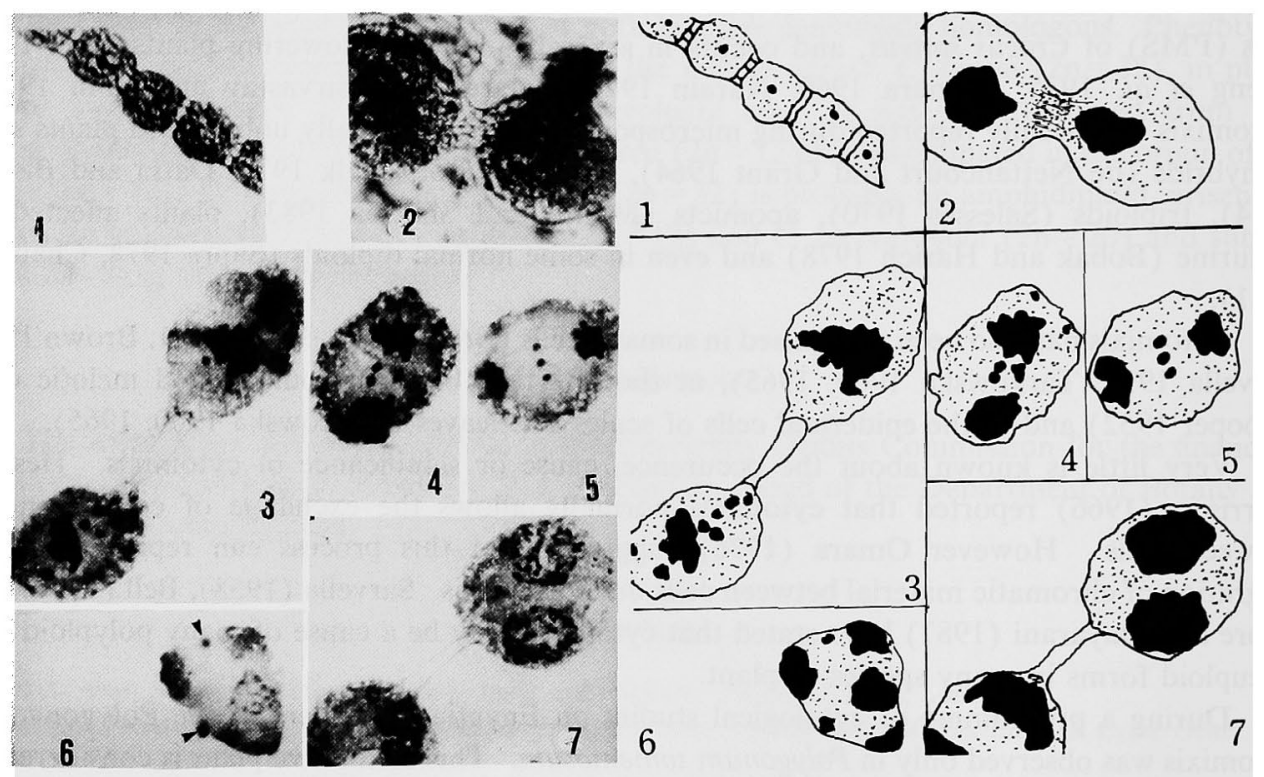

Figs. 1-7. 1. A series of PMC's showing cytoplasmic connections. 2. PMC's showing direct fusion during meiosis. 3. PMC's showing two cytoplasmic connections during cytomixis at metaphase I. 4, 5, 6. Abnormal anaphase I, telophase I and tetrade stages showing univalents and laggerds. 7. PMC's showing two cytoplasmic connections during cytomixis at prophase II.

Table 1. Number and percentage of cytomictic and abnormal PMC's and pollen fertility in Polygonum tomentosum L.

\begin{tabular}{|c|c|c|c|c|c|c|c|c|c|c|}
\hline \multirow{3}{*}{ F.C. } & \multirow{2}{*}{\multicolumn{2}{|c|}{$\begin{array}{c}\text { No. of } \\
\text { obser. cells }\end{array}$}} & \multicolumn{4}{|c|}{ No. of cytomictic cells } & \multirow{3}{*}{$\begin{array}{c}\% \text { of } \\
\text { cyto. cells }\end{array}$} & \multirow{2}{*}{\multicolumn{2}{|c|}{$\begin{array}{c}\% \text { of } \\
\text { abn. cells }\end{array}$}} & \multirow{3}{*}{$\begin{array}{c}\% \text { of } \\
\text { pollen fertility }\end{array}$} \\
\hline & & & \multicolumn{2}{|c|}{ MI } & \multicolumn{2}{|c|}{ MII } & & & & \\
\hline & MI & MII & C.C. & D.F. & C.C. & D.F. & & MI & MII & \\
\hline 1 & 230 & 200 & 45 & 11 & 23 & 3 & 19.06 & 33.2 & 22.9 & 70.4 \\
\hline 2 & 310 & 250 & 60 & 12 & 26 & 4 & 18.21 & 35.0 & 24.1 & 66.7 \\
\hline 3 & 200 & 170 & 45 & 12 & 23 & 3 & 22.43 & 30.6 & 20.7 & 66.6 \\
\hline 4 & 180 & 160 & 42 & 11 & 19 & 2 & 21.7 & 28.1 & 21.3 & 67.7 \\
\hline 5 & 210 & 180 & 43 & 10 & 22 & 3 & 20.0 & 28.9 & 19.5 & 69.7 \\
\hline G.M & 266 & 192 & 47 & 11.2 & 22.6 & 3 & 20.29 & 31.2 & 21.7 & 68.6 \\
\hline S.E & 20.1 & 14.3 & 2.54 & 0.33 & 1.09 & 0.28 & 0.71 & 1.16 & 0.73 & 0.69 \\
\hline
\end{tabular}

C.C. = cytoplasmic connection, D.F. = direct fusion, MI=meiosis I, G.M. = grand mean, cyto. =cytomixis, MII = meiosis II, abn. = abnormal, F.C. $=$ field collection, S.E. $=$ standard error 
A high proportion of meiotic cells (overall 31.2 in MI and 21.7 in MII), both those with and without cytomictic connections, displayed irregularities in the form of laggard chromosomes and univalents (Figs. 4, 5). This proportion also did not differ significantly between populations (Table 1). It seems probable that a combination of cytomixis and disturbed meioses leads to a high proportion of aneuploid pollen grains. Micronuclei are frequently observed in tetrads (Fig. 6). This suggestion is confirmed by mitotic chromosome counts reported by Nassar (1987) for this species in the same population, recording $2 n=54$, which represents on aneuploid form of the pentaploid number $(5 X=55$, where $X=11)$.

Not surprisingly, the disturbed and aneuploid cytology of pollen grains leads to the abortion of many, so that the average levels of pollen stainability are only $68.2 \%$. Once again, this figure does not differ significantly between populations (Table 1).

The factors responsible for cytomixis are not yet precisely understood. Various factors have been invoked, such as pathological conditions (Morrisset 1979), mechanical injury (Sarvella 1958), and a genetic control system (Mantu and Sharma 1983). In the present study seems very unlikely that cytomictic phenomena are caused by fixation artifacts, as was suggested by Jacob (1941), Takats (1959), or Gottschalk (1970). However in the present study, it is notable that meiosis are very disturbed, suggesting incomplete genomic homology, but it is less clear whether this is a primary or a secondary (postcytomictic) phenonemon. Another possibility that these populations at Rashid are hybridogenous between two members of the $P$. lapathifolium aggregate which show substantial levels of genomic differentiation, and this certainly needs further investigation.

\section{Summary}

Cytomixis, representing the migration of chromatic material from one cell to another, was observed in PMC's of Polygonum tomentosum Schrank. Cytomixis was observed at all stages of meiosis, but became less frequent in the later stages of meiosis. Direct nuclear fusion and cytoplasmic connections between cells were noted, so that a series of PMC's were sometimes connected togther.

Cytomictic cells were often accompined by other meiotic aberrations such as univalents, laggard and disoriented chromosomes. Levels of pollen stainability are low, indicating a high of male sterility in these populations.

\section{Acknowledgements}

The auther is grateful to Mr. M. A. Nassar, Suez Canal University for his help in collecting the material of this study and Dr. A. J. Richards, Department of Agriculture and Biological Science, University of Newcastle upon Tyne, England for critically reading the manuscript and making valuable comments.

\section{References}

Ahadi, K. K. and Sharma, A. K. 1981. Cytomixis in Laminaceae. Cytologia, 53: 167-174.

Akeroyd, J. F. 1993. Polygonum. In: Flora Europaea vol. I (ed. z) (eds. T. G. Tutin et al.), pp. 91-97. Cambridge University press, Cambridge.

Bahl, J. R. and Tyagi, B. R. 1988. Cytomixis in pollen mother cells of Papaver dubium L. Cytologia 53: $469-474$.

Basavaiah and Murthy, T. C. S. 1987. Cytomixis in pollen mother cellis of Urochloa panicoides P. Beauv (Poaceae). Cytologia 52: 69-74.

Bell, C. R. 1964. Cytomixis in Tauschia schl 1. (Apiaceae). Cytologia 29: 369-398.

Bobak, C. R. and Herich, R. 1978. Cytomixis as a manifestation of pathological changes after the application of 
trifluraline. The Nucleus 21(1): 22-26.

Bolkhovskikh, Z. Grif, V., Matvejeva, T., Zakharyeva, O. 1969. Chromosome Numbers of Flowering Plants. Academy of sciences, USSR.

Bowes, B. G. 1973. Note on apparent case of cytomixis in the root apex of Allium cepa. Cytologia, 38: $125-129$.

Brown, M. S. 1947. A case of spontaneous reduction of chromosome number in somatic tissues of cotton. Amer. J. Bot. 34: $38-388$.

Chauhan, A. K. S. 1981. Cytomixis in Papaver rhoeas. Inprespectives in cytology and genetics, Proc. Third. All India Congr. Cytol. Genet, 1878, Vol. 3, pp. 309-312. Hindasia publishers, Delhi.

Cheng, K. C., Neih, H. W., Yang, C. L., Wang, 1. H., Chou, I. S. and Chen, I. S. 1975. Light and electron microscopical observations on cytomixis and the study of its relation to evolution. Acta Bot. Sin. 17:60-69.

Cooper, D. D. 1952. The transfere of deoxyribose nucleic acid from the tapetum to the microsporocytes at the onset of meiosis. Amer. Nat. 86: 219-229.

Datta, A. K. and Biswas, A. K. 1984. Cytomixis and trisomic in Nigella sativa. Cytologia 49: 437-445.

de Nettacourt, D. and Grant, W. F. 1964. La cytogenetique de Lotus (Leguminoseae) III. un cas De cytomixie dans un hybride interspecifique. Cytologia 29: 191-195.

Gottschalk, W. 1970. Chromosome and nucleus migeration during microsporogensis of Pisum sativum. Nucleus 13(1): $1-9$.

Heslop-Harrision, J. 1966. Cytoplasmic connections between angiosperm meiocytes. Ann. Bot. 30: 221-230.

Jacob, K. T. 1941. Certain abnormalities in root tips of cotton. Curr. Sci. 10: 174.

Kamara, O. P. 1960. Chromatin extrusion and cytomixis in pollen mother cells of Hordium. Hereditas 64: $592-600$.

Kornicke, M. 1901. Uber ortsveranderung von zellkarnern. S.B. Niederrhein. Gas. Natur. U. Heilkunde Bonn. A. 1425.

Linnert, G. 1955. Cytologische Grundlagen fur sterilitatscheinung en in der Gattung Salvia. Der Zuchter. 25: 237241.

Mantu De and Sharma, A. K. 1983. Cytomixis in pollen mother cells of oranomental vatamia divaricata (Linn.) Alston. Cytologia 48: 201-207.

Morisset, P. 1978. Cytomixis in pollen mother cells of Ononis (Leguminosae) Can. J. Genet. Cytol. 20: $383-388$.

Narain, P. 1979. Cytomixis in pollen mother cells of Hemerocallis Linn. Curr. Sci. 48: 996-998.

Nassar, M. N. 1987. Morphological, palynlogical and cytological studies on Genus Polygonum L. in Egypt. M.Sc. Thesis University of Alexandria, Alexandria Egypt.

Omara, M. K. 1976. Cytomixis in Lolium prenne. Chromosoma 55: 261-271.

Salesses, G. 1970. Sur la phenomene de cytomixis chez hybrides triploides de prainier consequences genetique possibles. Ann. Amerlior pl. 20: 383-388.

Sapre, A. B. 1978. Cytomixis in trilobachne cookei (stafp) Schenck (Poaceae). Indian J. Bot. 1: $29-33$.

Sapre, A. B. and Dayarani, S. D. 1987. A change in chromosome number due to cytomixis in an interspecific hybrid of Coix L. Cytologia 52: 167-174.

Sarvella, P. 1958. Cytomixis and the loss of chromosome in meiotic and somatic cells of Gossypium. Cytologia 23: 1424.

Srivastav, P. K. and Raina, S. N. 1980. Cytomixis in Clitoria ternatea L. Var, pleniflora Fantz. f. pleniflora. curr. Sci. 49: 824-835.

Takats, S. T. 1959. Chromatin extrusion and DNA transfer during microsporogensis. Chromosoma 10: $430-453$.

Tarkoska, J. 1960. Cytomixis in epidermal of scales and leaves and in meristems of apex in allium cepa L. Acta. soc. Bot. Polon. 29: 149.

Tarkowska, J. 1965. Expermental analysis of the mechanism of cytomixis. I. cytomixis in vegetative tissues. Acta. Soc. Bot. Polon. 34: 27-44. 